\title{
Student Views on the Teaching of the Course of "Principles of Economic Theory" in Secondary Education in Greece
}

\author{
Aikaterini Polymili* \\ School of Economic and Regional Studies, Department of Economics, University of Macedonia, Greece
}

DOI: $10.36348 /$ jaep.2020.v04i02.004

| Received: 18.02 .2020 | Accepted: 25.02.2020 | Published: 29.02 .2020

*Corresponding author: Aikaterini Polymili

\section{Abstract}

This research was prompted by a reflection on the level of preparation and the way in which the course of Principles of Economic Theory is taught at the last grade of secondary education in Greece. Under the Greek system of access to tertiary education, this course determines, to a large extent, admission to university departments of economics. The research was conducted with students in a department of economics by investigating the degree of satisfaction from their high school preparation in relation to their decision to attend private supplementary teaching for the national admission exams to tertiary education. Additionally, there was an investigation into the choices of the educators as to the way in which the course in question was taught.

Keywords: Economic Theory, Greece tertiary, education.

Copyright @ 2020: This is an open-access article distributed under the terms of the Creative Commons Attribution license which permits unrestricted use, distribution, and reproduction in any medium for non-commercial use (NonCommercial, or CC-BY-NC) provided the original author and sources are credited.

\section{INTRODUCTION}

The instruction of economics courses appears in the end of the $18^{\text {th }}$ century in a college curriculum in the USA. Roughly a century later, the American Economic Association 1885 aims at advancing society by way of education on matters of economics, which would be achieved by redesigning the teaching curricula in colleges and universities. At the end of the $19^{\text {th }}$ century, economics courses constitute a separate discipline in university curricula, and, among other things, there is some emphasis given to the question of how they are taught. During the same period of time, the question of teaching economics courses in secondary education is also brought up. Reservations were initially expressed as to the maturity of the students to learn economic concepts, while a great scepticism was prevalent among university circles up until 1968 regarding the content of these courses and involving strong differences of opinion. At the same time, new research started on the adoption of the most suitable teaching methods for economics courses [1].

In the end of the 1960s and up until 1975, the teaching of economics courses comprised a major field of scientific research and teaching. Indeed, there was a seminar organized in 1973, meant primarily as a meeting place for researchers in economic education, in which there was an attempt to create a list of research topics on the subject. Since 1978, a number of economic education centres have been established (primarily in the USA), which function essentially within university economics departments, concentrating on the teaching of economics in secondary education. An international research seminar took place in England in 1995, focusing on the one hand on the development of syllabi for economics courses, and on the other on brainstorming ways in which these courses should be taught [2].

Nowadays, the teaching of economics courses in the international environment includes educational processes that involve editing of economics articles, devising work plans, using new technologies, etc. [1], something that has barely started happening in our country $[3,4]$.

In Greece, access to the tertiary education is done by means of national (Panhellenic) admission exams in four subject areas, depending on the four orientation groups selected by the students in their second (penultimate) high school grade. An analogous system was in effect for the school year 1992-1993, at which point, in the context of an effort to harmonize the Greek school system with its European peers, an economics course was tested for the first time on the national examination, determining admission to the tertiary education. In a European Council resolution in 1988 [5], several proposals and suggested actions were 
formulated for embedding economics courses in secondary education [6].

At present, the courses that are related to the economic science, and are taught by economists at high schools in Greece, are the following: (a) In first grade, "Political Education (Economy, Political Institutions and Principles of Law, and Sociology)," three hours per week; (b) in second grade, "Basic Principles of Social Sciences (Sociology, Economic Science, Political Science)," two hours per week (GG 3807/2018); and (c) in third grade (orientation group course), "Principles of Economic Theory" (PET), seven hours per week (GG 1790/2019). The course taught in third grade is tested on the nationwide examinations for admission to the tertiary education. For this reason, the teaching of the course is particularly important for the students who wish to be admitted to university schools of economics. Indeed, under the current Greek legislation, economists must obtain pedagogical and teaching qualification before they can teach in the secondary education, which they do primarily by attending the School of Pedagogical and Technological Education (ASPETE), or by obtaining an undergraduate, postgraduate or doctoral degree in the science of education ( $\mathrm{L}$. 3848/2010).

In Greece, despite the fact that there are 12 Departments of Economic Sciences (not counting the related sciences that can teach economics courses) in as many universities in the country, the departments that award pedagogical and teaching qualification are the Athens University of Economics and Business (AUEB) (GG 689/2013), and recently the University of Crete (L. 4547/2018). The graduates of all other Departments of Economic Science (and related sciences) in the country must obtain pedagogical and teaching qualification in the aforementioned ways.

It is known that the teaching of economics courses, along with all the other courses in secondary education, is based on the instructions issued by the Institute of Educational policy. The Institute, but also many teaching experts, propose a number of modern teaching methods and techniques (brainstorming, preparation of group assignments, seminar studies, article presentations, etc.) [7] in order to achieve the goals of the syllabus. However, the selection of teaching methods that encourage the student to develop initiative and self-motivation is up to the educators themselves [7, 8].

The teaching of economics courses also touches on everyday issues. Therefore, it would not be appropriate for the instructor to simply explain how the economy works and to teach the student problemsolving techniques. Due to the most rapid and diverse changes that occur in modern societies, the learner must develop an "economic" way of thinking, which can be achieved by using modern teaching methods and techniques. However, the use of such methods and techniques requires knowledgeable educators, both pedagogically and in terms of their teaching skills.

Thus, the adoption of methods and techniques that could be particularly useful in teaching economics, such as the use of new technologies [9], the project method $[10,11]$, etc., is not observed to any significant extent, much as it is not observed in the teaching of educators in other subject areas of secondary education, since their training is lacking $[12,8]$.

From the above, but also from the research results that follow below, it appears that even though economist educators are obliged to receive pedagogical and teaching training after obtaining their degree in order to teach in secondary education, they do not exploit it to any significant extent in their day-to-day teaching. This issue raises many questions, and is a subject that needs further investigation.

\section{Presentation of the research methodology and results Sample and aim of the research}

The basic aim of this research study is to probe students' views in terms of: (a) the effectiveness of the school in terms of preparing for the university entrance exams on the subject of the course of "Principles of Economic Theory" (PET); (b) their views on the time allocated in the curriculum for the instruction of the course; (c) the learning material handed out by the educators, and the supplementary exercises beyond those in the school textbook; (d) the teaching form and style followed by the educator; (e) the homework assignments; (f) the educator's preparation and devising of a course plan; (g) the course evaluation method within the school; and (h) the adequacy of the course preparation at school in terms of being able to succeed at the national exams without attending a private coaching school.

The research was carried out during the spring semester of the academic year 2017-2018, in the context of the course "Teaching Economics" of the Department of Economic Sciences of the University of Macedonia. The collection of data took place in May 2018.

The questionnaire contained 26 questions (21 closed-ended, and 5 questions offering a choice among more than one pre-formulated answers), including questions about the participating students' profile such as their gender, the orientation from which they were admitted to this particular university department, as well as their score at the national admission exams. The survey was conducted after the end of the "Teaching of Economics" course, without mandatory participation of those who attended the course. The time needed to fill out the questionnaire was 20 minutes on average. 
Statistical data analysis was performed using the statistical package spss 20.

The questionnaire was submitted to a total of 140 , and completed by 102 , students of the $6^{\text {th }}$ and $8^{\text {th }}$ semester of the Department of Economic Sciences of the University of Macedonia. Both genders are represented in the sample, since $33.3 \%$ (34 individuals) were male and $66.7 \%$ (68 individuals) female. Two individuals did not respond to this particular question.

The majority of the students $(81.2 \%)$ who were admitted to the school in question came from the technological orientation, $10.9 \%$ from the humanities orientation, and significantly fewer, $7.9 \%$, came from the natural sciences orientation.

\section{Analysis of the survey data and presentation of the results}

Presentation of the survey results via frequency analysis

One of the first questions that the students were asked was the score that they achieved at the national exams, and whether the university to which they ended up being admitted was among their top three choices. Student scores were binned, and the results indicate that $6.9 \%$ passed the admission exams with a score in the 70-84 points range, and as many in the $85-$ 89 points range (on a grading scale of $0-100$ ), $14.9 \%$ with 90-94 points, while a much higher percentage, $71.3 \%$, excelled achieving 95-100 points. Their answers also indicate that almost all participants $(97,1 \%)$ succeeded in being admitted to a school among their top three choices.

In Greece, high school students, in order to increase their chance of success at the university entrance examinations, elect to attend supplementary private education during one or more grades, either in groups ("frontistiria") or in private tutoring courses [13]. Therefore, the participating university students were asked about their attendance of frontistiria and private tutoring courses for the PET course during their high school years. Their answers indicate that almost half of them (48\%) attended some kind of supplementary instruction in the second (penultimate) and third (last) high school grades, $26.5 \%$ only in the third grade, and $23.5 \%$ in all three senior high school years. Concerning the kind of supplementary education that they attended, they indicated that $67.6 \%$ of them attended frontistiria, $26.5 \%$ had private tutoring lessons, and a very small percentage, $4.9 \%$, did not attend any kind of supplementary education besides school.

Regarding the level of the provided education in high school on the subject modules that are taught, $31.4 \%$ of the respondents consider it to be "inadequate," $41.2 \%$ find it "average," and $25.5 \%$ "quite good". Concerning the in-school preparation towards the national exams (in all the examined courses combined), $35.3 \%$ of the students qualified it as "inadequate," $45.1 \%$ as "average," $13.7 \%$ as "quite good," and only $4.9 \%$ consider it to be "very good". From these results, it follows that a significant majority of students, about $80 \%$, consider the effectiveness of the in-school preparation towards the university entrance examinations to be "inadequate" or "average". For the PET course in particular, $21.6 \%$ of the students take the view that the high school preparation for the admission exams to the tertiary education is "inadequate," $46.1 \%$ find it "average," $19.6 \%$ find it "quite good," and $9.8 \%$ "very good". There seems to be a small differentiation in the student opinion concerning the PET course compared to the global in-school preparation for the admission exams, since a cumulative $67.8 \%$ answered that it is "average" or "inadequate".

The next question was whether the PET teaching time in the third grade, based on the school curriculum, is adequate for an effective preparation of the students for the university entrance exams. From the participating university students, $8.8 \%$ estimated that the teaching time of the course is "inadequate," $46.1 \%$ that the teaching time is "somewhat" adequate, $36.3 \%$ that it is "rather" adequate, and only $8.8 \%$ that it is "fully" adequate.

Right afterwards, the participants were asked whether they did any supplementary exercises in the PET course, besides those included in the school textbook. It is an impressive finding that, during the PET preparation in school, one in four students did not do any additional exercises, while a very significant percentage, $27.5 \%$, did "a few" exercises. "Some" exercises were done by $13.7 \%$ of the students, while roughly 1 in 5 responded that they did "quite a few" additional exercises, and $12.7 \%$ that they did "many". Regarding the distribution of supplementary learning material for the PET course by the instructor, $29.4 \%$ and $25.5 \%$ of the students reported that they received "none" or a "small" amount, respectively. An "average" or a "considerable" amount was claimed to have been received by $18.6 \%$ of the respondents, the same for both categories, while $7.8 \%$ stated that they received a "copious" amount. Therefore, another important finding of this research is that more than half of the students (a cumulative of $54.9 \%$ ) received "none" or a "small" amount of learning material for a course that is on the university entrance exams, where the difficulty of the items is considerably higher than the level of the exercises in the school textbook.

The next questions concerned the profile of the instructor who was teaching the PET course in their school. In response to the question about the extent to which the educator was knowledgeable on the subject matter of the course, $17.6 \%$ of the participants stated that the educator was "very" knowledgeable, 41.2\% "quite" so, 30.4\% "average," and in much lower 
Aikaterini Polymili; J Adv Educ Philos, Feb 2020; 4(2): 49-59

percentages, $6.9 \%$ and $3.9 \%$, that the educator was "somewhat" or "not" knowledgeable, respectively. In other words, it seems that the survey participants consider the level of knowledge of the course instructors to be quite high.

Concerning the teaching form (confrontational, inquisitive, dialogic) [14] adopted by the educator in teaching the PET course, most respondents (57.8\%) replied that a combination of teaching forms was used (confrontational, inquisitive and dialogic), while roughly one in three students $(29.4 \%)$ replied that the educator was using the confrontational teaching form. The inquisitive and dialogic teaching forms were far less popular, at $5.9 \%$ and $6.9 \%$, respectively.

In relation to the teaching style followed by the educator at school, for about half the students $(50.5 \%)$ it was the "democratic" style, and only $6.9 \%$ report that the educator had an "authoritative" style. A very significant $42.6 \%$ of the participants responded that the educator adopted the "loose" teaching style. This style is characterized by a lack of close contact and communication between the educator and the students, a lack of planning in the educator's actions, pointless discussion with the students, and results in disappointment and a sense of failure on the part of the student [14]. One is justified in wondering how it can be that in the last high school grade, which is so critical in the Greek secondary education for the future of the students; educators do not try hard to make a substantial contribution to the successful participation of their students to the university entrance exams. One would normally expect that the educators charged with student preparation should be especially sensitive both in ascertaining their mastery of the subject matter and in helping to foster the students' self-confidence.

The student homework assignments, the type of these assignments, and the way of grading them, are all considered to be important educational issues [15] because, among other things, there are no exercises in the school textbook with a level of difficulty comparable to that of some exercises in the admission exams, as mentioned above. It is therefore crucial to the effective preparation of third-grade high school students to be assigned higher-level exercises to be worked on at home, so that the candidates can better prepare, thus improving response time to questions of greater difficulty and identifying their weaknesses. In response to the first question on homework assignments, 54.9\% answered that the teacher was assigning homework, while a very significant $45.1 \%$ that there was no assignment. From this finding, one would wonder how it is possible for the students to be adequately prepared at school for their participation to the national exams if they do not work on any exercise at home so as to improve their ability to deal with different exercises, similar to the ones encountered at the admission exams.
The type of homework that was assigned by the teachers was, in the vast majority of cases (91.2\%), individual. Of the participants who reported that they were taking homework assignments, $64.9 \%$ stated that these assignments were "corrected in the classroom," $22.8 \%$ stated that "some were corrected in the classroom and some by the teacher at home," and $12.3 \%$ that "the teacher was correcting by himself/herself at home" all the homework assignments. Particularly encouraging is the significant percentage of exercises that are corrected in the classroom, since in this way students can identify their weaknesses, expand their way of thinking, and become better prepared for the exercises that they will have to tackle in the national university entrance examination. Of the number of exercises assigned to the candidates, $42.1 \%$ of the surveyed students stated that "all" exercises were corrected, $15.8 \%$ that "many" were corrected, $26.3 \%$ "some," while $10.5 \%$ and $5.3 \%$ "a few" or "none", respectively. Although, according to the student responses, the cumulative percentage $(15.8 \%)$ of those reporting that "a few" or "none" of the assigned exercises were corrected is relatively low, one could say that it is actually very high when it refers to the preparation of a course that is important for the admission exams, and indeed the only required course for entrance to economics schools.

With regard to the frequency of the educator's preparation in general $[16,4]$, and for the instruction of the PET course in particular, $36.1 \%$ of the participating students responded that the educator would "sometimes" come prepared to their class. This percentage is too high, considering that the PET course is taught at last high school grade which is of critical importance for the candidates' admission to tertiary education. However, a significant $22.7 \%$ and $23.7 \%$ of the educators would come to their class prepared "always" or "most times", respectively. Smaller, though still not negligible, percentages came to class "sometimes" or "never" prepared (14.4\% and 3.1\%, respectively).

Further, the university students participating in the survey were asked whether, in their opinion, the educator was following a course plan. Approximately one in four $(25.7 \%)$ stated that the educator "was not devising" a course plan, $32.7 \%$ that the educator "was making a plan," and $41.6 \%$ that the educator "was sometimes following a plan". It is well known that the course plan is a critical factor for the evaluation of the teaching results, as it allows the educator to specify the course objectives, to design and apply the teaching, to identify the student needs, and to evaluate the result so that corrections may be implemented if there are any shortcomings or delays $[17,18]$. Therefore, it is a source of concern when an educator does not prepare a course plan to ensure the maximum possible teaching effectiveness, especially in the last high school year, that is, the year when students prepare for their 
admission to tertiary education. Is this a case of unwillingness, of ignorance, or of discrediting the use of this necessary tool? Does the role of the civil servant take priority over the role of the teacher? Are some educators so certain that the students attend external supplementary coaching that they do not bother designing and organizing their course? Is it a consequence of some educators' belief that thanks to their experience there is no need for a course plan? All the above constitute important questions for future research.

Another notable finding of this work is the observation, according to the statements of the survey participants, that in the vast majority of cases $(82.2 \%)$ the blackboard was the only teaching tool used by the instructor, with just $13.9 \%$ involving "sometimes" the use of other teaching tools. It seems, therefore, that economist educators prefer in their majority to use the traditional blackboard in their teaching, and avoid making use of new technologies. This fact is yet another paradox in the teaching of economist educators, since the economics courses, by their own nature, could be taught with modern tools, inciting stronger student interest in the course.

In relation to the evaluation methods used by the educators who were teaching in the schools attended by participating students, they had the possibility of selecting more than one evaluation method. Their answers are shown in table 1 below.

Table-1: Evaluation methods

\begin{tabular}{|l|c|}
\hline \multicolumn{1}{|c|}{ Evaluation methods } & Percentage (\%) \\
\hline Worksheet at the end of each teaching module & 7.9 \\
\hline Test every few lessons & 19.8 \\
\hline Test per chapter & 28.7 \\
\hline Test per combination of chapters & 27.7 \\
\hline Hourly examination & 45.5 \\
\hline Unannounced tests/examinations & 17.8 \\
\hline Preannounced tests/examinations & 42.6 \\
\hline
\end{tabular}

From the above findings, it seems that educators tend to use hourly and preannounced tests ( $45.5 \%$ and $42.6 \%$, respectively), while a number of them prefer to check their students' progress, and to identify possible problems in their understanding of the learning material, using tests per chapter $(28.7 \%)$ and tests per combination of chapters $(27.7 \%)$.

In answering the question about the PET teaching level at school, $43.6 \%$ of the surveyed students said that the course was taught "well," about one in five $(20.8 \%)$ that it was taught "not well," $23.8 \%$ "quite well," a much smaller percentage (11.9\%) "very well," and just 3\% "extremely well". These results might explain to a large extent the reason for which today's university students decided, as high school students, to attend "frontistiria" in order to increase their chances of success at the national exams.

Furthermore, the participants, now from the position of a university student, responding to the question of whether the PET modules taught at school gave a comprehensive overview of the course, estimated that the overview was "not" comprehensive $(10.0 \%)$, "somewhat" comprehensive (39\%), "quite" so $(37 \%)$, and only $10 \%$ "very" comprehensive. On the basis of these findings, one could say that the selection and the extent of the subject matter for the PET course, as taught in the last high school year, does not provide the students with a clear overview of economic theory, and that as a consequence, the authorities should perhaps consider a revision of the subject matter of this course.
Moreover, an important finding is that $68.3 \%$ of the survey participants state that they "would not have been able to answer some" admission exam questions had they not attended "frontistiria". This finding amplifies the previous response of the (university) students that, in their majority, were taught the PET course "well" or "quite well" (cumulative sum of $67.4 \%$ ), and therefore not well enough to deal with all the admission exam questions exclusively on the basis of the school preparation. However, about one in three $(31.7 \%)$ state the opposite, i.e., that they would be able to successfully tackle all national exam questions with in-school preparation alone.

For the next question, if the possibility of attending supplementary teaching for PET were offered at school, $50.5 \%$ of the survey students responded that "they would participate," while $42.6 \%$ said that they "might" participate in such a program. The last question was whether they believe that a supplementary teaching program could replace "frontistirio" as far as the requirements of the third high-school grade are concerned, to which $26.7 \%$ responded that "it could," while an important percentage $(43.6 \%)$ that "perhaps it could". However, one in three students respond that this could not happen. From the answers to the last two questions, it seems that the large majority of the survey participants would participate to supplementary teaching programs at school. 
Aikaterini Polymili; J Adv Educ Philos, Feb 2020; 4(2): 49-59

\section{Presentation of the survey results via cross-tabulation analysis}

The frequency analysis was followed up by an investigation of the correlation probability of certain variables which could help reach further conclusions. The investigation focused on two main issues. The first one concerns student preparation in the PET course for the national exams in relation to the teaching time, the attendance of out-of-school supplementary education by the students, and the teacher training. The second issue concerns the teacher preparation regarding the form and style of teaching, as well as the use of a course plan.

First, the private coaching school ("frontistirio") attendance for the PET course was cross-tabulated to the level of preparation at school for this particular course. The results show a statistically significant correlation of medium association (table 2).

Table-2: PET private coaching ("frontistirio") and PET preparation at school

\begin{tabular}{|c|c|c|c|c|c|c|c|c|}
\hline & \multicolumn{5}{|c|}{ PET preparation at school } & \multirow[t]{2}{*}{ Total } \\
\hline & & & Inadequate & Average & $\begin{array}{l}\text { Quite } \\
\text { good }\end{array}$ & $\begin{array}{l}\text { Very } \\
\text { good }\end{array}$ & $\begin{array}{c}\text { Fully } \\
\text { adequate }\end{array}$ & \\
\hline \multirow{6}{*}{$\stackrel{-5}{2}$} & \multirow[t]{2}{*}{ "Frontistirio" } & Frequency & 15 & 32 & 17 & 4 & 1 & 69 \\
\hline & & Percentage & $21.70 \%$ & $46.4 \%$ & $24.6 \%$ & $5.8 \%$ & $1.4 \%$ & $100.0 \%$ \\
\hline & \multirow{2}{*}{$\begin{array}{l}\text { Private } \\
\text { tutoring }\end{array}$} & Frequency & 7 & 13 & 2 & 4 & 1 & 27 \\
\hline & & Percentage & $25.9 \%$ & $48.1 \%$ & $7.4 \%$ & $14.8 \%$ & $3.7 \%$ & $100.0 \%$ \\
\hline & \multirow[t]{2}{*}{ Neither } & Frequency & 0 & 1 & 1 & 2 & 1 & 5 \\
\hline & & Percentage & $0.0 \%$ & $20.0 \%$ & $20.0 \%$ & $40.0 \%$ & $20.0 \%$ & $100.0 \%$ \\
\hline \multirow{2}{*}{\multicolumn{2}{|c|}{ Total }} & Frequency & 22 & 46 & 20 & 10 & 3 & 101 \\
\hline & & Percentage & $21.8 \%$ & $45.5 \%$ & $19.8 \%$ & $9.9 \%$ & $3.0 \%$ & $100.0 \%$ \\
\hline
\end{tabular}

Among the students who participated in the survey, 24.6\% attended "frontistirio" for the PET course during their high-school studies, even though they considered the in-school preparation to be "quite good". Among the participants who did not attend any kind of supplementary schooling, $40 \%$ estimated that the preparation at school is "very good". However, 20\% of the university students who considered the PET preparation at school to be "average," decided not to receive supplementary schooling.
A significant statistical correlation (strong association) came to light from the cross-tabulation of the adequacy of the level of preparation for the PET course at school to the time allocated for its instruction on the basis of the curriculum (table 3). It follows from the answers of the survey respondents that those considering the preparation at school as "inadequate" or "average", estimated that the teaching time was only "somewhat" adequate (at 50\% and 61.7\%, respectively).

Table-3: PET Preparation and Teaching Time

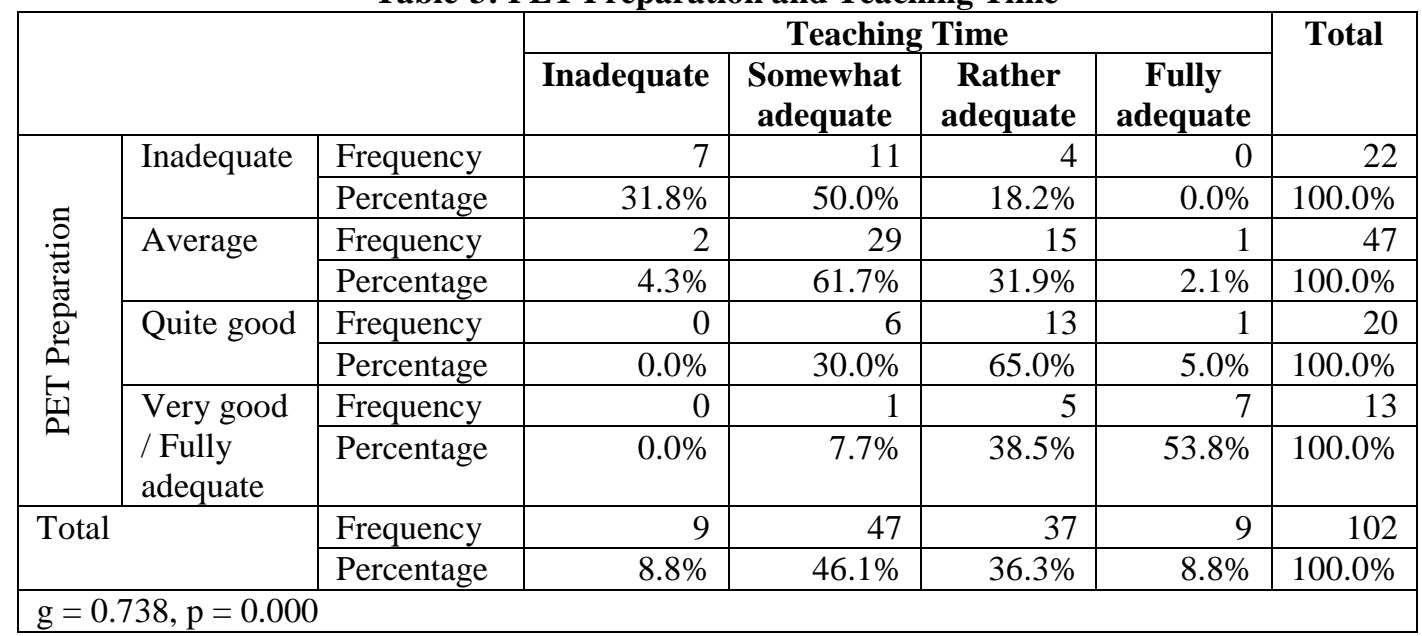

One might assume that the survey participants consider the course teaching time to be a crucial factor in their evaluation of the preparation at school.

A similar result comes out of the relation between the level of preparation for PET and the educator training, where a statistically significant correlation of strong association is evident (table 4). Those students who estimate the preparation to be "average", also consider the training of the educator who taught this particular course to be "average" (at $40.4 \%$ ). Considering that, as generally acknowledged, the size of the subject matter is small, and the level of difficulty on the theoretical side of the course is limited 
Aikaterini Polymili; J Adv Educ Philos, Feb 2020; 4(2): 49-59

to a very basic introduction to the subject of microeconomic theory, one wonders what are the reasons for which, according to the respondents, the educator training is only "average". Are these reasons related exclusively to the educator's limited scientific background, or do they pertain to the way in which the course is taught, which requires a pedagogical and teaching capacity?

Table-4: PET Preparation and Educator Training

\begin{tabular}{|c|c|c|c|c|c|c|c|c|}
\hline & \multicolumn{5}{|c|}{ Educator Training } & \multirow[t]{2}{*}{ Total } \\
\hline & & & 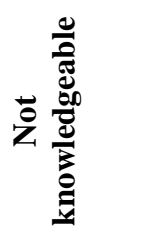 & 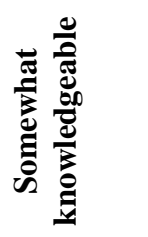 & 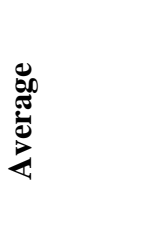 & 总 & 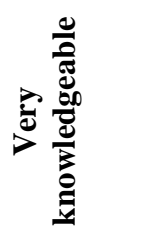 & \\
\hline \multirow{8}{*}{ 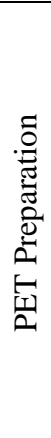 } & \multirow[t]{2}{*}{ Inadequate } & Frequency & 2 & 4 & 12 & 3 & 1 & 22 \\
\hline & & Percentage & $9.1 \%$ & $18.2 \%$ & $54.5 \%$ & $13.6 \%$ & $4.5 \%$ & $100.0 \%$ \\
\hline & \multirow[t]{2}{*}{ Average } & Frequency & 1 & 3 & 19 & 18 & 6 & 47 \\
\hline & & Percentage & $2.1 \%$ & $6.4 \%$ & $40.4 \%$ & $38.3 \%$ & $12.8 \%$ & $100.0 \%$ \\
\hline & \multirow[t]{2}{*}{ Quite good } & Frequency & 1 & 0 & 0 & 14 & 5 & 20 \\
\hline & & Percentage & $5.0 \%$ & $0.0 \%$ & $0.0 \%$ & $70.0 \%$ & $25.0 \%$ & $100.0 \%$ \\
\hline & \multirow{2}{*}{$\begin{array}{l}\text { Very good } \\
\text { / Fully } \\
\text { adequate }\end{array}$} & Frequency & 0 & 0 & 0 & 7 & 6 & 13 \\
\hline & & Percentage & $0.0 \%$ & $0.0 \%$ & $0.0 \%$ & $53.8 \%$ & $46.2 \%$ & $100.0 \%$ \\
\hline \multirow{2}{*}{\multicolumn{2}{|c|}{ Total }} & Frequency & 4 & 7 & 31 & 42 & 18 & 102 \\
\hline & & Percentage & $3.9 \%$ & $6.9 \%$ & $30.4 \%$ & $41.2 \%$ & $17.6 \%$ & $100.0 \%$ \\
\hline
\end{tabular}

Based on the above, it is reasonable to conclude the existence of a strong association in the cross-tabulation between PET preparation in school and the teaching level of the course (table 5). Among the university students who participated in the survey,
$61.9 \%$ said that the preparation in school was "inadequate" because the teaching level was "not good". Moreover, $59.6 \%$ of them responded that the "average" preparation for the exams was attained with of a "good" teaching level.

Table-5: PET Preparation and PET Teaching Level

\begin{tabular}{|c|c|c|c|c|c|c|c|c|}
\hline & \multicolumn{5}{|c|}{ PET Teaching Level } & \multirow{3}{*}{$\begin{array}{r}\text { Total } \\
\\
21\end{array}$} \\
\hline & & & \multirow{2}{*}{$\begin{array}{r}\frac{\text { Not }}{\text { good }} \\
13\end{array}$} & \multirow{2}{*}{$\begin{array}{r}\text { Good } \\
8\end{array}$} & \multirow{2}{*}{$\begin{array}{l}\begin{array}{l}\text { Quite } \\
\text { good }\end{array} \\
0\end{array}$} & \multirow{2}{*}{$\begin{array}{r}\begin{array}{l}\text { Very } \\
\text { good }\end{array} \\
0\end{array}$} & \multirow{2}{*}{$\begin{array}{r}\text { Excellent } \\
0\end{array}$} & \\
\hline \multirow{8}{*}{ 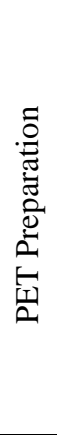 } & \multirow[t]{2}{*}{ Inadequate } & Frequency & & & & & & \\
\hline & & Percentage & $61.9 \%$ & $38.1 \%$ & $0.0 \%$ & $0.0 \%$ & $0.0 \%$ & $100.0 \%$ \\
\hline & \multirow[t]{2}{*}{ Average } & Frequency & 8 & 28 & 10 & 1 & 0 & 47 \\
\hline & & Percentage & $17.0 \%$ & $59.6 \%$ & $21.3 \%$ & $2.1 \%$ & $0.0 \%$ & $100.0 \%$ \\
\hline & \multirow[t]{2}{*}{ Quite good } & Frequency & 0 & 8 & 8 & 4 & 0 & 20 \\
\hline & & Percentage & $0.0 \%$ & $40.0 \%$ & $40.0 \%$ & $20.0 \%$ & $0.0 \%$ & $100.0 \%$ \\
\hline & \multirow{2}{*}{$\begin{array}{l}\text { Very good / } \\
\text { Fully } \\
\text { adequate }\end{array}$} & Frequency & 0 & 0 & 3 & 7 & 3 & 13 \\
\hline & & Percentage & $0.0 \%$ & $0.0 \%$ & $23.1 \%$ & $53.8 \%$ & $23.1 \%$ & $100.0 \%$ \\
\hline \multirow{2}{*}{\multicolumn{2}{|c|}{ Total }} & Frequency & 21 & 44 & 21 & 12 & 3 & 101 \\
\hline & & Percentage & $20.8 \%$ & $43.6 \%$ & $20.8 \%$ & $11.9 \%$ & $3.0 \%$ & $100.0 \%$ \\
\hline
\end{tabular}

Concerning the supplementary exercises that the respondents were taught for the given teaching time, there is a statistically significant correlation of medium association. Those who did "a few" or "no" supplementary exercise at school $(55.6 \%$ and $44.4 \%$, respectively) consider that there was "inadequate" teaching time for this course (table 6). Conversely, those who consider the teaching time to be "fully" adequate did "quite a few" supplementary exercises $(44.4 \%)$. 
Aikaterini Polymili; J Adv Educ Philos, Feb 2020; 4(2): 49-59

Table-6: Teaching Time and Supplementary Exercises

\begin{tabular}{|c|c|c|c|c|c|c|c|c|}
\hline & \multicolumn{5}{|c|}{ Supplementary Exercises } & \multirow[t]{2}{*}{ Total } \\
\hline & & & None & A few & Some & $\begin{array}{c}\text { Quite a } \\
\text { few }\end{array}$ & Many & \\
\hline \multirow{8}{*}{ 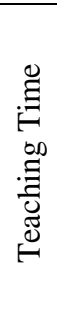 } & \multirow[t]{2}{*}{ Inadequate } & Frequency & 4 & 5 & 0 & 0 & 0 & 9 \\
\hline & & Percentage & $44.4 \%$ & $55.6 \%$ & $0.0 \%$ & $0.0 \%$ & $0.0 \%$ & $100.0 \%$ \\
\hline & \multirow{2}{*}{$\begin{array}{l}\text { Somewhat } \\
\text { adequate }\end{array}$} & Frequency & 17 & 17 & 2 & 4 & 7 & 47 \\
\hline & & Percentage & $36.2 \%$ & $36.2 \%$ & $4.3 \%$ & $8.5 \%$ & $14.9 \%$ & $100.0 \%$ \\
\hline & \multirow{2}{*}{$\begin{array}{l}\text { Rather } \\
\text { adequate }\end{array}$} & Frequency & 5 & 6 & 9 & 13 & 4 & 37 \\
\hline & & Percentage & $13.5 \%$ & $16.2 \%$ & $24.3 \%$ & $35.1 \%$ & $10.8 \%$ & $100.0 \%$ \\
\hline & \multirow{2}{*}{$\begin{array}{l}\text { Fully } \\
\text { adequate }\end{array}$} & Frequency & 0 & 0 & 3 & 4 & 2 & 9 \\
\hline & & Percentage & $0.0 \%$ & $0.0 \%$ & $33.3 \%$ & $44.4 \%$ & $22.2 \%$ & $100.0 \%$ \\
\hline \multirow{2}{*}{\multicolumn{2}{|c|}{ Total }} & Frequency & 26 & 28 & 14 & 21 & 13 & 102 \\
\hline & & Percentage & $25.5 \%$ & $27.5 \%$ & $13.7 \%$ & $20.6 \%$ & $12.7 \%$ & $100.0 \%$ \\
\hline
\end{tabular}

Similarly, $44.4 \%$ and $55.6 \%$ of the survey participants replied that when the teaching time was "inadequate," they received "no" or a "small" amount of supplementary teaching material, respectively (a statistically significant correlation of medium association) (table 7).

Table-7: Teaching Time and Supplementary Material

\begin{tabular}{|c|c|c|c|c|c|c|c|c|}
\hline & & & \multicolumn{5}{|c|}{ Supplementary Material } & \multirow[t]{2}{*}{ Total } \\
\hline & & & None & $\begin{array}{c}\text { Small } \\
\text { amount }\end{array}$ & Average & $\begin{array}{c}\text { Considerable } \\
\text { amount }\end{array}$ & $\begin{array}{l}\text { Copious } \\
\text { amount }\end{array}$ & \\
\hline \multirow{8}{*}{ 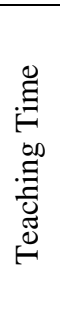 } & \multirow[t]{2}{*}{ Inadequate } & Frequency & 4 & 5 & 0 & 0 & 0 & 9 \\
\hline & & Percentage & $44.4 \%$ & $55.6 \%$ & $0.0 \%$ & $0.0 \%$ & $0.0 \%$ & $100.0 \%$ \\
\hline & \multirow{2}{*}{$\begin{array}{l}\text { Somewhat } \\
\text { adequate }\end{array}$} & Frequency & 18 & 16 & 5 & 4 & 4 & 47 \\
\hline & & Percentage & $38.3 \%$ & $34.0 \%$ & $10.6 \%$ & $8.5 \%$ & $8.5 \%$ & $100.0 \%$ \\
\hline & \multirow{2}{*}{$\begin{array}{l}\text { Rather } \\
\text { adequate }\end{array}$} & Frequency & 7 & 5 & 12 & 10 & 3 & 37 \\
\hline & & Percentage & $18.9 \%$ & $13.5 \%$ & $32.4 \%$ & $27.0 \%$ & $8.1 \%$ & $100.0 \%$ \\
\hline & \multirow{2}{*}{$\begin{array}{l}\text { Fully } \\
\text { adequate }\end{array}$} & Frequency & 1 & 0 & 2 & 5 & 1 & 9 \\
\hline & & Percentage & $11.1 \%$ & $0.0 \%$ & $22.2 \%$ & $55.6 \%$ & $11.1 \%$ & $100.0 \%$ \\
\hline \multirow{2}{*}{\multicolumn{2}{|c|}{ Total }} & Frequency & 30 & 26 & 19 & 19 & 8 & 102 \\
\hline & & Percentage & $29.4 \%$ & $25.5 \%$ & $18.6 \%$ & $18.6 \%$ & $7.8 \%$ & $100.0 \%$ \\
\hline
\end{tabular}

As far as the perception of the educator who taught the course to the now-university students, some important information emerges, characterized by strong statistical correlations. By cross-tabulating educator training to apparent level of preparation for teaching the course, one obtains a statistically significant correlation (of medium association). Those participants who considered the educator to be "very knowledgeable"
$(68.8 \%)$ estimate that the educator "always" came to class prepared (table 8). Those estimating that the educator training was "average," respond that the educator was "most times" prepared for teaching. One wonders whether it is enough for an educator to go to class prepared "most times", especially in the last highschool grade, where student preparation for the national exams should be as thorough as possible.

Table-8: Educator Training and Educator Preparation

\begin{tabular}{|c|c|c|c|c|c|c|c|c|}
\hline & \multicolumn{5}{|c|}{ Educator Preparation } & \multirow[t]{2}{*}{ Total } \\
\hline & & & Never & Sometimes & $\begin{array}{l}\text { Most } \\
\text { times }\end{array}$ & $\begin{array}{l}\text { Many } \\
\text { times }\end{array}$ & Always & \\
\hline \multirow{8}{*}{ 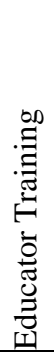 } & \multirow{2}{*}{$\begin{array}{l}\text { Not / } \\
\text { Somewhat } \\
\text { knowledgeable }\end{array}$} & Frequency & 2 & 4 & 4 & 1 & 0 & 11 \\
\hline & & Percentage & $18.2 \%$ & $36.4 \%$ & $36.4 \%$ & $9.1 \%$ & $0.0 \%$ & $100.0 \%$ \\
\hline & \multirow[t]{2}{*}{ Average } & Frequency & 0 & 9 & 14 & 6 & 0 & 29 \\
\hline & & Percentage & $0.0 \%$ & $31.0 \%$ & $48.3 \%$ & $20.7 \%$ & $0.0 \%$ & $100.0 \%$ \\
\hline & \multirow{2}{*}{$\begin{array}{l}\text { Quite } \\
\text { knowledgeable }\end{array}$} & Frequency & 1 & 1 & 14 & 14 & 11 & 41 \\
\hline & & Percentage & $2.4 \%$ & $2.4 \%$ & $34.1 \%$ & $34.1 \%$ & $26.8 \%$ & $100.0 \%$ \\
\hline & \multirow{2}{*}{$\begin{array}{l}\text { Very } \\
\text { knowledgeable }\end{array}$} & Frequency & 0 & 0 & 3 & 2 & 11 & 16 \\
\hline & & Percentage & $0.0 \%$ & $0.0 \%$ & $18.8 \%$ & $12.5 \%$ & $68.8 \%$ & $100.0 \%$ \\
\hline \multirow{2}{*}{\multicolumn{2}{|c|}{ Total }} & Frequency & 3 & 14 & 35 & 23 & 22 & 97 \\
\hline & & Percentage & $3.1 \%$ & $14.4 \%$ & $36.1 \%$ & $23.7 \%$ & $22.7 \%$ & $100.0 \%$ \\
\hline
\end{tabular}


Concerning the educators' level of preparation versus the form of teaching that they adopted for their course, a statistically significant correlation of medium association was identified, since the form of teaching selected by the majority of the educators was a combination of lecture, question and discussion irrespective of their level of preparation for the teaching of the course (table 9). However, the educators who were "many times" or "more" prepared opted for the confrontational form of teaching.

Table-9: Educator Preparation and Form of Teaching

\begin{tabular}{|c|c|c|c|c|c|c|c|}
\hline & \multicolumn{4}{|c|}{ Form of Teaching } & \multirow[t]{2}{*}{ Total } \\
\hline & & & $\begin{array}{c}\text { Confrontational } \\
\text { (Lecture) }\end{array}$ & $\begin{array}{l}\text { Inquisitive } \\
\text { (Question) }\end{array}$ & $\begin{array}{c}\text { Dialogic } \\
\text { (Discussion) }\end{array}$ & Combination & \\
\hline \multirow{8}{*}{ 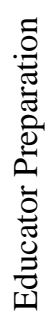 } & \multirow{2}{*}{$\begin{array}{l}\text { Never / } \\
\text { Sometimes }\end{array}$} & Frequency & 4 & 2 & 2 & 9 & 17 \\
\hline & & Percentage & $23.5 \%$ & $11.8 \%$ & $11.8 \%$ & $52.9 \%$ & $100.0 \%$ \\
\hline & \multirow{2}{*}{$\begin{array}{l}\text { Many } \\
\text { times }\end{array}$} & Frequency & 15 & 1 & 1 & 18 & 35 \\
\hline & & Percentage & $42.9 \%$ & $2.9 \%$ & $2.9 \%$ & $51.4 \%$ & $100.0 \%$ \\
\hline & \multirow{2}{*}{$\begin{array}{l}\text { More } \\
\text { times }\end{array}$} & Frequency & 9 & 3 & 1 & 10 & 23 \\
\hline & & Percentage & $39.1 \%$ & $13.0 \%$ & $4.3 \%$ & $43.5 \%$ & $100.0 \%$ \\
\hline & \multirow[t]{2}{*}{ Always } & Frequency & 2 & 0 & 2 & 18 & 22 \\
\hline & & Percentage & $9.1 \%$ & $0.0 \%$ & $9.1 \%$ & $81.8 \%$ & $100.0 \%$ \\
\hline \multirow{2}{*}{\multicolumn{2}{|c|}{ Total }} & Frequency & 30 & 6 & 6 & 55 & 97 \\
\hline & & Percentage & $30.9 \%$ & $6.2 \%$ & $6.2 \%$ & $56.7 \%$ & $100.0 \%$ \\
\hline
\end{tabular}

The cross-tabulation of the educator's level of teaching to the adopted teaching style yields a statistically significant correlation of high association (table 10). Each one (100\%) of the survey participants estimates that the educator who "never" came prepared for teaching adopted a "loose" teaching style. Conversely, the educator who "always" came prepared for teaching followed the "democratic" style $81.8 \%$ of the time.

Table-10: Educator Preparation and Teaching Style

\begin{tabular}{|c|c|c|c|c|c|c|}
\hline & \multicolumn{3}{|c|}{ Teaching Style } & \multirow{3}{*}{$\begin{array}{r}\text { Total } \\
3 \\
\end{array}$} \\
\hline & & & Authoritative & Democratic & Loose & \\
\hline \multirow{10}{*}{ 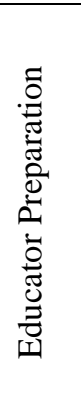 } & \multirow[t]{2}{*}{ Never } & Frequency & 0 & 0 & 3 & \\
\hline & & Percentage & $0.0 \%$ & $0.0 \%$ & $100.0 \%$ & $100.0 \%$ \\
\hline & \multirow[t]{2}{*}{ Sometimes } & Frequency & 2 & 2 & 10 & 14 \\
\hline & & Percentage & $14.3 \%$ & $14.3 \%$ & $71.4 \%$ & $100.0 \%$ \\
\hline & \multirow[t]{2}{*}{ Many times } & Frequency & 0 & 17 & 17 & 34 \\
\hline & & Percentage & $0.0 \%$ & $50.0 \%$ & $50.0 \%$ & $100.0 \%$ \\
\hline & \multirow[t]{2}{*}{ Most times } & Frequency & 4 & 14 & 5 & 23 \\
\hline & & Percentage & $17.4 \%$ & $60.9 \%$ & $21.7 \%$ & $100.0 \%$ \\
\hline & \multirow[t]{2}{*}{ Always } & Frequency & 0 & 18 & 4 & 22 \\
\hline & & Percentage & $0.0 \%$ & $81.8 \%$ & $18.2 \%$ & $100.0 \%$ \\
\hline \multirow{2}{*}{\multicolumn{2}{|c|}{ Total }} & Frequency & 6 & 51 & 39 & 96 \\
\hline & & Percentage & $6.3 \%$ & $53.1 \%$ & $40.6 \%$ & $100.0 \%$ \\
\hline
\end{tabular}

Concerning the educator's level of preparation versus the devising of a course plan, there is a statistically significant correlation of strong association (table 11). A total of $54.3 \%$ of the participants replied that the educator who was "averagely" prepared was "sometimes" following a course plan, whereas the educator having done a "very" good preparation was "always" following a course plan. 
Aikaterini Polymili; J Adv Educ Philos, Feb 2020; 4(2): 49-59

Table-11: Educator Preparation and Course Plan

\begin{tabular}{|c|c|c|c|c|c|c|}
\hline & \multicolumn{3}{|c|}{ Course Plan } & \multirow[t]{2}{*}{ Total } \\
\hline & & & Yes & No & Sometimes & \\
\hline \multirow{4}{*}{ 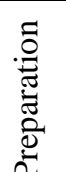 } & \multirow{2}{*}{$\begin{array}{l}\text { Not / } \\
\text { Somewhat }\end{array}$} & Frequency & 0 & 10 & 6 & 16 \\
\hline & & Percentage & $.0 \%$ & $62.5 \%$ & $37.5 \%$ & $100.0 \%$ \\
\hline & \multirow[t]{2}{*}{ Averagely } & Frequency & 7 & 9 & 19 & 35 \\
\hline & & Percentage & $20.0 \%$ & $25.7 \%$ & $54.3 \%$ & $100.0 \%$ \\
\hline \multirow{4}{*}{ 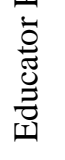 } & \multirow[t]{2}{*}{ Quite } & Frequency & 8 & 4 & 11 & 23 \\
\hline & & Percentage & $34.8 \%$ & $17.4 \%$ & $47.8 \%$ & $100.0 \%$ \\
\hline & \multirow[t]{2}{*}{ Very } & Frequency & 15 & 2 & 5 & 22 \\
\hline & & Percentage & $68.2 \%$ & $9.1 \%$ & $22.7 \%$ & $100.0 \%$ \\
\hline \multirow{2}{*}{\multicolumn{2}{|c|}{ Total }} & Frequency & 30 & 25 & 41 & 96 \\
\hline & & Percentage & $31.3 \%$ & $26.0 \%$ & $42.7 \%$ & $100.0 \%$ \\
\hline
\end{tabular}

\section{CONCLUSIONS AND DISCUSSION}

It follows from the preceding research results that the majority of students believe that the preparation for the PET course in high school is inadequate, and the teaching time limited. For this reason, one could claim that they choose to attend out-of-school supplementary education in order to increase their chances of admission to an economics school in tertiary education. As far as the educators are concerned, the participating students responded that while they are knowledgeable in their subject matter, they make limited use of modern teaching methods and techniques. Roughly half of them do not devise a course plan, do not distribute supplementary learning material, do not give homework assignments, do not make use of new technologies. One positive point is that they follow a mixed form of teaching (implementing lecture, question and discussion in the class), and are not limited to lecturing. It is surprising that, while economist educators obtain pedagogical and teaching qualification which requires at least one year of studies (ASPETE) beyond their basic degree, which means that they have an advantage over their colleagues of other disciplines, they do not apply what they have been taught in order to improve the level of their teaching, and produce beneficial learning outcomes. Therefore, it is necessary to probe the choices of economist educators with respect to the preparation and realization of their teaching in Greek secondary education.

\section{Laws}

Law 3848/19-5-2010: Enhancement of the teaching profession - establishment of evaluation and meritocracy rules in education, and other provisions.

Law 4547/12-6-2018: Reorganization of the support structures of primary and secondary education, and other provisions. Article 111: Pedagogical and teaching qualification.

Government Gazette vol. B' 689/26-3-2013: Provision for pedagogical and teaching qualification in the Curricula of the Teaching and Education Sciences of the AUEB.
Government Gazette 1842 vol. B'/26-8-2015: Call for Expression of Interest by candidate educators of Primary and Secondary Education for inclusion in the tables of auxiliary and supply teachers for the school year 2015-2016.

Government Gazette 3807 vol. B'/4-9-2018: Curricula for General High School grades $A^{\prime}, B^{\prime}$ and $\mathrm{C}^{\prime}$.

Government Gazette 1790 vol. B'/21-5-2019: Amendment of ministerial decree 139454/D2/28-082018 on "Curricula for General High School grades A',

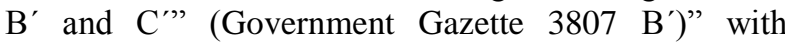
respect to the curriculum for General High School grade $\mathrm{C}^{\prime}$.

\section{REFERENCES}

1. Bourletidis, K. (2010). Economic Education: Theories and techniques of teaching. Athens: Evrasia.

2. Whithead, D., \& Makridou-Bousiou, D. (2006). Economic education. Teaching economics: A manual for economics teachers. Athens: Gutenberg.

3. Giossi, S., \& Dagdilelis, V. (2015). The instruction of economics and business administration courses. Thessaloniki: University of Macedonia Publications.

4. Brinia, V. (2006). General and special teaching of economic sciences (tertiary education). Psychopedagogy for economic sciences. Athens: Stamoulis.

5. Eur-Lex, Access to European union law: https://eur-lex.europa.eu/legalcontent/EL/TXT/?uri=CELEX\%3A41988X0706\% $2801 \% 29$ (recovered on 2/10/2019)

6. Pantidis, S., \& Passias, K. (2003). European dimension in education. Athens: Gutenberg.

7. Chatzidimou, D. (2011). "Alternative shapes, techniques and teaching methods" in: users.att.sch.gr (assesd 22/10/2019). 
8. Chatzidimou, D., \& Chatzidimou, K. (2010). The training of General and Technical-Vocational Education teachers today: a critical examination, in: Nea Pedeia. 134, 69-78.

9. Sosin, K., \& Goffe, W. (2006). "Using the internet and computer technology to teach economics", in Teaching Economics: More alternatives to chalk and talk (ed: Becker, W., Watts, M. \& Becker, S.). UK: Edward Elgar publishing limit.

10. Taratori-Tsalkatidou, H. (2010). The project method in theory and in practice. Thessaloniki: Kyriakidis Bros Publication.

11. Brinia, V. (2007). Introduction of the project method (empirical - interactive teaching) in the teaching of economics courses. A manual. Athens:Gutenberg.

12. Xohellis, P. (2018). Introduction to Pedagogy. Fundamental problems of the science of pedagogy. Thessaloniki: Kyriakidis bros Publication.

13. Polymili, A. (2016). The Tutorial Institute (Frontistirio) as a Latent Structural Element of the Greek Educational System: High School (Lyceum) Students' Opinions. Athens: Diadrasi.
14. Chatzidimou, D. (2019). Introduction to the subject of teaching. Thessaloniki: Kyriakidis Bros Publications.

15. Chatzidimou, D. (2006). Student homework assignments. Thessaloniki: Kyriakidis Bros Publications.

16. Chatzidimou, D., \& Chatzidimou, K. (2014). The planning of teaching in theory and in practice. Educational-teaching techniques, course plans, and teaching seminars for primary, middle and high school. Athens: Diadrasi.

17. Chatzidimou, D. (1988). Course preparation and planning. Thessaloniki: Kyriakidis Bros Publications.

18. Makridou-Bousiou, D. (2005). Issues on learning and teaching. Thessaloniki: University of Macedonia Publications.

19. IEP. (2019): Press release, 2019 curriculum: http://iep.edu.gr/images/IEP/GENERAL/Deltia_Ty pou/2019/Program_spoudon_G_GEL/\%CE\%A0\% CE\%A3_\%CE\%91\%CE\%9F\%CE\%98_\%CE\%93_ $\% \mathrm{CE} \% 93 \% \mathrm{CE} \% 95 \% \mathrm{CE} \% 9 \mathrm{~B} . \mathrm{pdf}$ (recovered on 7/10/2019) 